\title{
An Interview with Dr. Beth Simone Noveck
}

\section{The former U.S. Deputy Chief Technology Officer and the author of Wiki Government: How Technology Can Make Government Better, Democracy Stronger and Citizens More Powerful discusses open government and what it really means.}

\author{
Interviewed by Peter Kinnaird
}

DOI: 10.1145/2043236.2043245

\section{PETER KINNAIRD: Could you please describe your former role in the White House and what you're doing these days?}

BETH NOVECK: I served from 2009 to 2011 as the first United States Deputy Chief Technology Officer. In that capacity, I was the founder and had primary responsibility for something we called the White House Open Government Initiative [http://www.whitehouse.gov/open]. I sat within the White House Office of Science and Technology Policy [OSTP]. I recently returned to my job as a Professor of Law at New York Law School. It was also recently announced that I was appointed as a Senior Advisor on Open Government to Prime Minister Cameron.

\section{PK: Tell us about some of the initiatives} you were involved with at the White House. In particular, could you describe both successes and failures?

BN: I really don't think there's any such thing as a failure in the work that I do. Everything is an experiment, trying to devise ways to use new tools-whether technology, law, or policy-to develop better ways for government to make smart decisions. Even before serving in the White House, I designed Peer to Patent. Built in 2006, it was the first expert networking system within the federal government of the U.S. It was a Web-based system that was designed to allow volunteer scientists and technologists to provide feedback and information to the patent office about pending patent applications. It was really about designing not just a tool, but the rules and social practices that go into

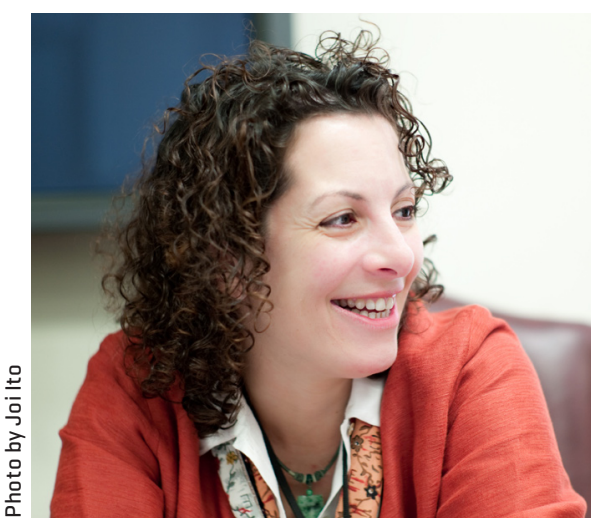

Beth Noveck

implementing a system that would allow citizens to participate in the design making process used by a government agency. The simple idea behind Peer to Patent was to discover how we can connect the network to the institution to make the institution smarter and better informed. That project is really one that is paradigmatic in terms of the notion that people are smart and have lots of good ideas, experience, and enthusiasm to contribute that can help our public institutions function better. Our public institutions desperately need access to good information and expertise quickly and also in a form that's useful and usable. That's why an appreciation of humancomputer interaction is so crucial!

\section{PK: What project were you most excited about?}

BN: One favorite project that I worked on together with the National Archives and the Government Printing Office was the revamp of the Federal Register [http://www.federalregister.gov/]. For the last 75 years, the federal government of the U.S. has published a daily newspaper about the workings of the federal government-a place where you can read and find information about the pending rules and actions that are taken by the government that might affect you. And for 75 years, that newspaper has looked like very hard to read legalese in a multicolumn PDF. The kind of thing that's so dense that people hire lawyers to read it for them and tell them whether there's information relevant to their daily lives.

So by simply making the dataset of the old federal register downloadable online, three programmers in San Francisco, in an effort to win a contest [Apps for America], were able to take that dataset and redesign in three months what the register looks like now: A more graphical, interactive magazine where you can actually filter information to see what's relevant to you. So now you can go to federalregister.gov and read the newspaper and see what's going on that you care about. I think what happened in that three-month period in 2010 is as revolutionary and important for transparency as what happened in the 75 years prior. It really opens up a whole new window by creating a really useful, friendly way to see this information. I think over time the new presentation is not only increasing readership, but it will also improve the way people write for the Federal Register. Because government officials are now writing for a magazine instead of a legal brief, they will make the content more transparent, accessible and inviting.

PK: It's commonly observed, especially in 
online systems, that a few items or areas get lots of interest and attention with a very long tail of other interests. How do you view this phenomenon with respect to the kinds of collaborative democracy initiatives you've helped with, and how have you addressed it?

BN: I describe this phenomenon as the "Publisher's Clearinghouse of democracy." Publisher's Clearinghouse has a magazine for everybody, be it Golf Digest or Cat Fancy. The whole notion of open innovation for government is that there's someone out there who has expertise, interest, and passion around some topic, whether it's patents, the environment, or transportation. If we can create systems that allow us to tap that enthusiasm, we can greatly increase participation in our democracy, and improve the intelligence of our institutions. So one of the counterintuitive ideas behind the open government concept is that voting, while essential to our democracy, is kind of a monolithic, one-size-fits-all system. Technologists and designers know that you often have to have different ways of visualizing or accessing information to make it intelligible to people. It's the same concept here behind what you refer to as the long tail of democracy, which is that we need to create lots of different ways for people to participate based on their personal interests, talents, and passions. At the moment we have far too few ways for people to get involved.

\section{PK: President Obama's transition team set up a site where people could post any question they wanted. Many of the top questions were about the legalization of marijuana. Having so many of the top questions concerned with the same issue is definitely a problem. I'm curious how you've designed some of your projects to deal with that? How have you thought about this issue?}

BN: I think this comes back to the idea of designing ways of getting information that is useful and implementable. I'm not saying that this might not be a perfectly valid and politically important suggestion that people are demanding their elected leaders consider, but I think one of the primary impediments to participation right now is that we don't have the mechanisms either in terms of social practice or technology by which people can share ideas with their congressperson, the White House, or an agency in a form that's actually useful to those public servants. Thinking back to my job in the White House, on any given day I worked on a 100 different topics and had a huge number of meetings and things to do. If someone contacted me with a suggestion, either in the form of a two-line tweet or a 60-page academic paper, in neither form could I easily implement or act on that idea. So the notion of creating tools and systems where we can translate ideas into action is extremely important. That's going to require lots of conversations and work between computer scientists and lawyers, civil servants and designers, politicians and data junkies, hackers and bureaucrats, in order to understand both how things work now and how we can use technology to improve how they work over time.

One of the core reasons that Peer to Patent took off is that we designed the system to create feedback to the patent office in a manageable quantity and in accordance with the legal rules. It wasn't about just giving officials any information, but about enabling the delivery of specific legally relevant information about the patent application. We also made it easy for contributors to understand what was expected of them and made it simple enough to contribute that people wouldn't have to jump through hoops to participate. All that is to say that Twitter and Facebook may not always be the solution to how we make complex policy within government.

\section{PK: What can our readers, computer science undergraduate and graduate students, do now to help out?}

BN: It's really important that students remember how important they are to the future of our democracy. We've had a longstanding principle of transparency in our democracy, but it wasn't until we created data.gov, the national data portal, that we were able to translate the principle of data transparency into practice at scale. The notion of accountability is core to our democracy, but it wasn't until we created USASpending.gov that again we translated the principle of popular oversight into practice. So I think the first thing is for students to recognize that they have a role to play. It's not only relevant to them as citizens in our democracy, but it's relevant to them as computer scientists, engineers, and designers. They have a role to play in public service that they might not have considered before. One thing they can do is educate themselves about areas of policy that interest them, whether it's transportation, the environment, or any other area, because I'm certain that there are opportunities for them to apply what they are learning technically to the innumerable public sector opportunities, problems and challenges that we face today.

Second, they should consider public service, whether as a career, an internship, or a short stint. All the agencies at the federal level, the state level, or the local level are desperate for people with technical expertise. For example, check out the Office of Science and Technology Policy's internship. OSTP would love to hire computer science students. I think one of the most important things we did as part of the open government initiatives was make sure that agencies started hiring CTOs, technologists with responsibility, not simply making sure that the servers are working, but as senior advisors to the secretaries, senior members of the policy making team. Bringing in and having a federal CIO and CTO sends the signal that technologists are incredibly important to developing solutions to today's social problems.

The third place they should go is to a website called geeksforwonks.org, which we've setup for listing students who are engaged in any kind of projectbased learning, especially people who are doing software projects to list their interests and skills so that public officials can help to send projects their way. For example, the Consumer Product Safety Commission is trying to think about how to redesign their website with \$25 million from Congress. This commission's mission is to improve safety for things like toys and cribs. It takes really talented technologists to think about ways to help protect parents and kids, designing and implementing better ways to use this kind of technology and information.

\section{PK: Thank you so much for your time!}

\section{Biography}

Peter Kinnaird is a Ph.D. student at Carnegie Mellon's Human-Computer Interaction Institute with an M.S. in human-computer interaction and a B.S. in computer science from The Georgia Institute of Technology. 